Imágenes en Urología

\title{
Perforación uretral y vesical por malla de uretropexia TOT
}

Silvia Álvarez Bandrés, Antonio Hualde Alfaro, Luis Ripa Saldías, Álvaro De Pablo Cárdenas, José L. Cebrian Lostal, José D. Jiménez Parra

Servicio de Urología. Hospital Virgen del Camino. Pamplona. Navarra. España.

$\mathrm{P}$ aciente de 67 años sin antecedentes de interés, con historia de incontinencia urinaria de esfuerzo, intervenida de uretropexia TOT. A los cinco meses se practicó corte de la malla suburetral por un cuadro de urgencia e inestabilidad vesical, tras lo cual presentó recidiva de su incontinencia de tipo mixto, confirmada mediante estudio urodinámico. Se asociaba además clínica de escozor vaginal que refería estar presente desde el momento de la intervención inicial y aumentaba con la micción. Tras una exploración ginecológica rigurosamente normal, se practicó cistoscopia, objetivando la existen-

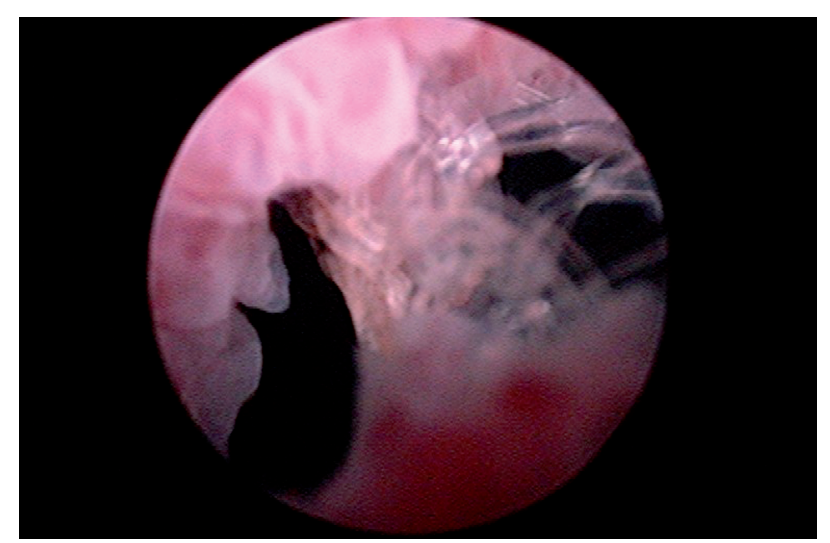

FIGURA 1. Aspecto endoscópico de la malla perforando uretra media.

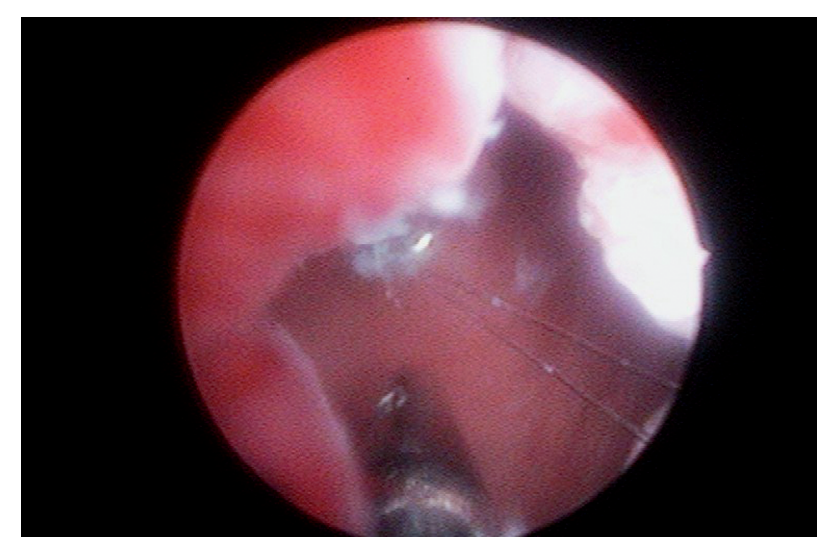

FIGURA 3. Extracción endoscópica con pinza de cuerpos extraños y tijera endoscópica. cia de una perforación a nivel de uretra media y cuello vesical por hilos de la malla de polipropileno de la técnica antiincontinencia inicial. Con dificultad se procedió a la extracción endoscópica del material extrusionado. La paciente fue dada de alta el mismo día con cobertura antibiótica.

Correspondencia autor: Dra. Silvia Álvarez Bandrés Servicio de Urología. Hospital Virgen del Camino Irunlarrea, 4 - 31008 Pamplona. Tel.: 848429400 E-mail autor: silvia81mdc@hotmail.com Información artículo: Imágenes en Urología Trabajo recibido: enero 2008

Trabajo aceptado: febrero 2008

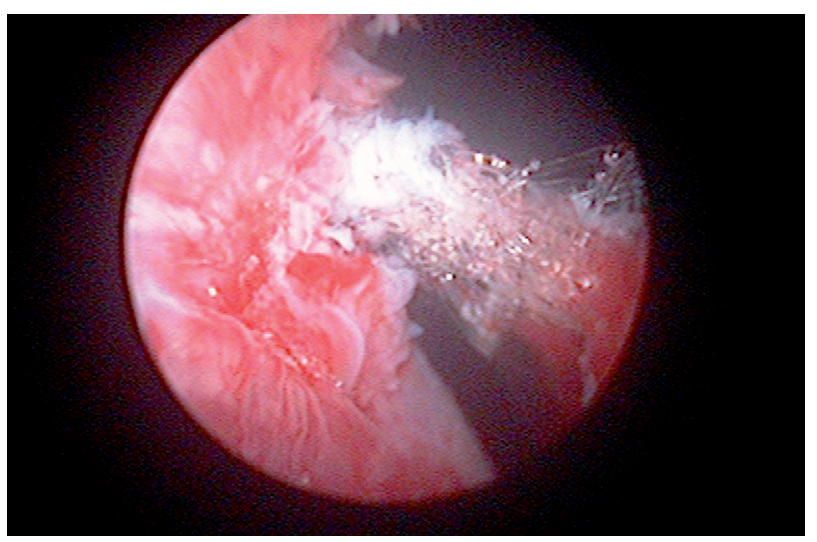

FIGURA 2. Aspecto endoscópico de la malla perforando cuello vesical.

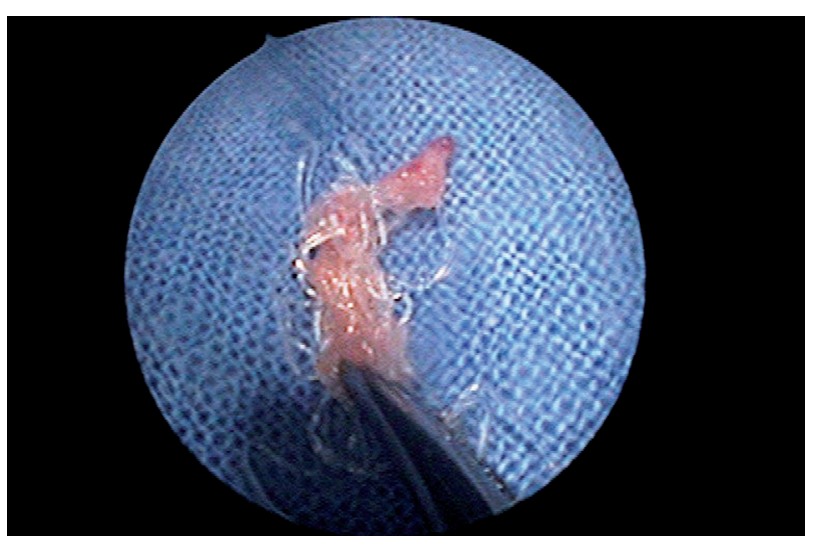

FIGURA 4. Aspecto de la malla tras su extracción endoscópica. 